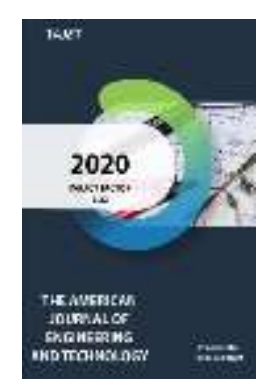

\title{
Architectural Development Of Amir Temur Mausoleum In XIV- XV Centuries
}

\section{Nilufar Tukhboeva}

Senior Teacher, Faculty Of Architecture, Tashkent Architecture And Construction Institute, Uzbekistan

\footnotetext{
Journal Website:

http://usajournalshub.c

om/index,php/tajet

Copyright: Original content from this work may be used under the terms of the creative commons attributes 4.0 licence.
}

\section{ABSTRACT}

In this article the new information is given about the forming of the Amir Timur mausoleum's ensemble which was famous by the name of Guri Amir.

Archaeological excavations conducted in 1943-1970 revealed that the foundations of the courtyards were much higher than the medresses and bedsheets and did not even have a foundation under the courtyard wall.

\section{KEYWORDS}

Tomb, madrasa, mosque, complex, ensemble, roof, dome, sufa, sardoba, myonsarai, tower, graves.

\section{INTRODUCTION}

\section{Problem solving}

Between the 14th and 15th centuries $A D$ in the southwestern part of Samarkand, a new architectural monument, erected on the instructions of Amir Timur's great granddaughter, Prince Sultan, was erected. In 1404, Amir Timur ordered the ensemble to build a mausoleum, which later became the last place for the elder and his relatives.
There are many contradictory opinions on the mausoleum of Amir Timur Mausoleum, known as Gur Emir, to the western and southern sides of the mausoleum, but to identify the missing structure and to bury Muhammad Sultan.

Even among some scholars there was an idea that historic-fiction literature, such as the poet Maliho, did 
not refer to Muhammad Sultan, but to Amir Timur's dynasty, his teacher, Mir Saeed Baraka.

\section{The Level Of Knowledge Of The Problem}

About Amir Timur and Timurids architecture Zahiriddin Muhammad Babur, Sharafiddin Ali Yezdi, Abdurazzak Samarkandiy, Abu Tohirhoja Samarkandiy, Nizomiddin Shamiy, Giyosiddin Ali Yazdi, Ibn Arabshoh, Hondamir, Rui Gonzales de Klavixo, V. Bartold, A. Yu. Yakubovsky, B. Ahmedov, V. L. Vyatkin, B. Valihodzhaev, T. N. Qori-Niyazi, G. A. Pugachenkova, L. I. Rempel, M. E. Masson, X. P. Sultonov, O'. Alimov, M. E. Pletnev, Yu. Z. Schwab, P. Sh. Zohidov, O. Buriev, M. Q. Ahmedov, T.Sh. And analyzed by Shirinov et al. However, there are many shortcomings in the information published on the basis of the ideology of the former regime of Amir Timur Mausoleum, built in the time of Amir Timur and the last Timurids, and some buildings built in other cities, and these deficiencies require scientific grounds.

\section{TASK}

To clarify this, the following scientific issues will be addressed:

Analyzing and comparing the century's data;

Comparison of century data with archaeological data;

- The discovery of the laws of establishment and development of the complex, consisting of buildings of various periods;

- Architectural composition of buildings, definition of constructive solutions;

- To develop new scientific conclusions. Based on these, resolve the uncertainty about the tomb of Amir Timur.

\section{DESCRIPTION OF THE MAIN MATERIAL}

As you know, Amir Timur is Samarkand's capital. Throughout his lifetime, he is engaged in the beautification of Samarkand, the streets, and construction of the magnificent buildings.

The entrance to the complex consists of a square roof, square-shaped courtyard, the ruins of the madrasah on the left side, the basements on the western side of the courtyard, the tomb in the south and the remains of an unfinished building adjacent to it.

Researchers have provided various information on this issue. V.V.Bartold, B.N.Zasipkin, V.L. Vyatkin, P.Sh. Zohidov, M.E.Masson, I.E.Pletnev, G.A.Pugachenkova, M.Saidjonov, Ya.G. Gulomov and A.Berdimurodov consider that the madrasah and mausoleum were constructed in the period of Muhammad Sultans, and the tomb building was constructed on the order of Amir Timur as a domed building.

I.E. Pletnev, Yu.Z. Shvab and V.V. Bartolt Yazdi's translation of the "Zafarnoma" have come to the same conclusion as translator V.V. Bartold [1]. We have the manuscript of Sharafiddin Ali Yazdi personally known as V.V.Bartold. He questioned the accuracy of the translation carried out by Bartold. Translated by V.V. Bartold: "... was ordered to build a domed mausoleum next to the madrassah; according to the decree, the dome of the oscillating dome was restored in front of the court room ... "[2]

Here is V.V. Bartold speaks twice about the dome and states that it is the only domed dome

Rui Gonzales de Clavijo writes: "On the thirteenth of October, the senor (Amir Timur) went to school and stopped at a mosque where he ordered his grandson Maxam Soltan (Muhammad Sultan). The Senor liked this grandson and therefore ordered that mosque, house and mausoleum (we distinguished by Ahmedov M, Tokhbayeva N).

Clavijo that the Amir Timur in the book dedicated to his grandson in a domed mausoleum, "ordered the builders of mosques, houses and tombs". In order to 
clarify the issue, we refer to the original (facsimile) text of Yazdi:

سمرقند بداخل اندازد قالب بر بقاو حيات بيرتو كـ آساروج آنجا از و ...

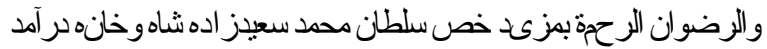

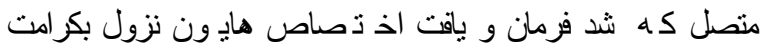

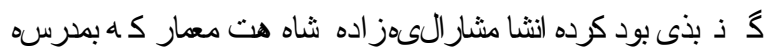

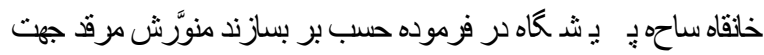

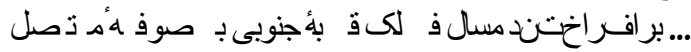

The interpretation and translation of the text in the Cyrillic alphabet:

"'... and from the site (Sahibkiran from the garden of Baland (high) - Akhmedov $M$, Tukhbayeva N.), ... From there he came to Samarkand, the heartbeat of life and immortality, and went to the house of Sayyid Muhammad Sultan, a madrassa set up by the late prince, Allah took him to mercy and forgave his sins. The decree was given to his dwelling place to be restored. On this assignment, they began to carry a galley wall to the southern part of the square in the square [3]. "

Focusing on attentively, at past wasted details, it can be said that the two buildings are regarding to build two types of domes. The first of them is to go to the madrasah and to close the gravestone (sardoba), and the second one is the restoration of a dome to the southern part of the toilet.

The foundations of Muhammad Sultan's monastery and the remains of the building on the western side of the mausoleum have not yet been uncovered during V.V. Bartold and V.L.Vyatkin's reign. Today's data and their analysis The Yezidis have a huge domed myonious behind the roof, with two hinged towers in the corner of Hijjah Ahmad Yassaviy, the mausoleum of Jahongir in Shahrisabz, Sayfiddin Boharziy in Bukhara, Qaffol Shashi in Tashkent, Zangi Ota and other corners of the two minarets of the Amir Timur era, behind it is a dome-shaped mausoleum and about a huge chamber-mausoleum surrounding a number of cells.

Indeed, the Bibikhanum mosque in Samarkand, the White Serai in Shakhrisabz, the Hoja Ahmed Yassaviy room in Turkistan, and the son of the late son of the great Sahibkiran, the son of the great son of Amir Timur, who built the magnificent buildings of 50-70 $\mathrm{m}$ height, it is unbelievable that he built a domed mausoleum for Muhammad Sultan. Sahibkiran started a two-dome building and completed his rest in 10 days, set up a Koran, and made a trip to China. Because of his accidental death, the great pilgrimage will not be completed.

I.E.Pletnov misinterpreted the salient construction and wrote that "it started in the 15th century and lasted less in the XVII century." [4] However, this author's poetry scenes, brick sizes, and other conclusions are unclear.

According to V. V. Bartold, Mirzo Ulugbek, as well as Amir Timur, tried to decorate Samarkand with magnificent buildings, and the appearance of Gur Emir was also found in Mirzo Ulugbek [5]. Indeed, it is the eastern corridor, the grave, the grave on the first floor of the mausoleum, and other works of its time. Even the entry point and the entrance to it are more like the period of Ulugbek. 
Archaeological excavations conducted in 19431970 revealed that the foundations of the courtyards were much higher than the medresses and bedsheets and did not even have a foundation under the courtyard wall.

We believe that this work should be done in accordance with Mirzo Ulugbek. I.E.Pletnev himself mentions that the madrasah and mausoleum were recovered from the bricks of $26-28 \times 26 \times 28 \times 5-6 \mathrm{~cm}$ used in the Timurid era, and the upper part of the gallery was made of $25 \times 25 \times 5 \mathrm{~cm}$ bricks of the period of Mirzo Ulugbek [6]. There are a number of evidence to indicate that the construction of the Amu Darya mosque in southern and western sides of Muhammad Sultan's mausoleum has already begun.

First of all, it can be seen in the composition of the buildings erected in the time of Amir Timur, which was also used in mausoleums built by Amir Timur, such as Chashmai Ayyub in Bukhara, Khoja Ahmed Yassaviy in Turkestan, Jahangir Sultan in Shahrisabz, and Abdu Dorun in Samarkand. On both sides of the facade of these buildings, the two towers are composed of two additional toilets, which are arranged in front of the portal entrance and covered with dome, and several additional rooms on each side. The first dome (dome) is lower, the diameter is larger and the other is much higher. It can be found on the foundations of the foundation.

The architectural design of Amir Timur Mausoleum is the octal prism that carries large circular cylindrical shaped circles. The bottom of the dome is 15 meters long and 12.5 meters in height, but does not feel weight. The reason for this is that the dome, which is 64 ribs, is a solid foundation, with a striking shadow. The dimensions of the bricks used in the construction of the building ensured the smooth distribution of the tension in the building, because the bricks were square.

A great deal of emphasis on the composition and thickness of bricks. When designing wall structures, it was found that bricks and mixing structures combined the effects of external forces and maintained a uniform "elasticity" of the whole design during the operation. Using mathematical or geometric methods, constructing buildings and constructions by measuring the dimensions and dimensions of a building in a particular geometrical shape, complying with architectural harmony laws.

There are more than 20 "F" and "P" figures in the "golden ratio" used in the size of the mausoleum.

Secondly, the restoration of this building during the reign of Amir Timur $(28 \times 28 \times 6,5 \mathrm{~cm})$ used bricks, gray marble, limestone marble used the same size of a brick building and construction technology side-by-side with the school, the courtyard is paved with bricks and technology used quite different.

Thirdly, I.E. Pletnyov finds that there is another foundation at the depth of $80 \mathrm{~cm}$ under the basement of an unfinished southern myonian mound. This is the first foundation found in the author of the period of Amir Timur. If this idea is correct, then the unfinished construction began not by Ulugbek but by Amir Timur. Mirzo Ulugbek built the entrance to the entrance, the galleries, and arranged the outer appearance and courtyard of the mausoleum. As a result, the floor was upgraded to $0.8 \mathrm{~m}$ and another part of the underground chamber, which was considered to belong to a huge building which was not directly built on the south side of the mausoleum. I. Pletnyov said that these two 
mammoths were destroyed at the same time, one of them belonged to the time of Amir Timur. The second building in the same uncompleted underground building was also discovered by the time of Amir Timur [7].

The base of the mausoleum (at the south-east corner) serves to receive the burden of the dome, which is very clearly constructed and consists of several layers of building materials: the tomb is below the bottom of the tile -0.8 $\mathrm{m}$, and the gray marble tile $-0,29 \mathrm{~m}$; There are $0.22 \mathrm{~m}$ marble plating beneath the brick, and the next layer is $0.65 \mathrm{~m}$ of limestone limestone, with the silica-like shale part found in the "hill" mixture, where the "hill" mixture is replaced with gray.

The overall wall height of the foundation wall is $3.97 \mathrm{~m}$ [8]. Tombstones, cement boards and ceilings are fitted with a marble plaque and the bricks are to be loaded (bricks below the blanket, previously marble limestone, below the silicon silica shrubs, construction gypsum, hill and gray blend and the location of the ground is a rare occurrence in the practice of ancient construction. Therefore, the construction of this unfinished construction may be considered by Amir Temur on his order.

Here are some interesting facts from the book Arminiy (Herman) Vamberi: "Turbati Temur (Temur's grave) is located on the south-east of the city. Here is a very beautiful dome, a tomb which is surrounded by a wall. There are two smaller dome-shaped domes on both sides of the high gate. Trees are planted between walls and mausoleums. "Amir Temur has expanded its surroundings around the mausoleum:" [Turb] destroyed several houses around [the mausoleum] and created a garden that reminds of the garden garden ", writes Sharafiddin Ali Yazdi. [9]

The entrance to the mausoleum is on the eastern side, as a rule, towards Mecca, namely, to Qibla (means Altar). The big graves are located at the head. In the East, there are two roles (chests or stables) with the sacred books. Here, there is a rally (in the basement of Gur Amir Mausoleum - Akhmedov M.), with a large Koran set on the skin of a Giselle (deer). Majority people expostulate me that here are this Koran was copied by the secretary of Muhammad SAW. and his second caliph Usman, then Amir Temur brought him from the treasury of Sultan Boyazid in Bursa. [10]

This information confirms that our towers in the north-eastern and south-eastern sides belong to the Muhammad Sultan madrasah, and the two minarets on the opposite side were built by Mirzo Ulugbek during the restoration of the courtyard facades of the 15th century. However, it should be understood that the arrangement of the ensemble and territory of the ensemble and territory by Mutribi was that Muhammad Sultan's madrasah had been built by Mirzo Ulugbek, which turned it into a boiler like Hoja Ahmed Yassaviy's room in Turkestan, where there is a great boiling today.

It should be noted that, while determining the date of construction that was not completed during Ulugbek's construction, I. Pletnyov denied his findings and constructed the main parts of these buildings, built by Amir Temur (Tuman Aga mausoleum, Bibi Khanim, Kozizada Rumi's two-domed mausoleum). He actively supports the position of Yassaviy mausoleum in terms of architecture. 
According to the source analysis, in the end of the XIV century, land was purchased in the ancient Chakar district of Samarkand and Muhammad Sultan madrassah was built and in March 1404, Muhammad Sultan's coffin was brought from Sultan to Samarkand and was temporarily buried in the left corner of the madrassah. Later, this room of the madrassah was transformed into the male descendants of the Temurians, and the dome in the righthand corner was transformed into a herd of women. When Amir Temur came to visit Muhammad Sulton's grave in July 1404, he ordered a large and magnificent construction.

By the way, according to the historian Yezidi information and the foundations of the foundations, it is planned to be similar to two domes, i.e. Khoja Ahmed Yassaviy mausoleum in Turkistan. In August-September of 1404, Muhammad Sulton's coffin was moved from the madrasah to the tomb.

The well-known scientist Omonulla Buriev can solve another historical mystery through Yezdi information, "he added. Thus, in the 1409 renovation of this historic mausoleum, it describes the bodies on Amir Temur's mausoleum:

Later, particularly during the reign of Mirzo Ulugbek, some changes were made to this mausoleum; the body of Amir Temur, who died suddenly in February 1405, was visited by the grave of Shohruh Mirzo, father of Amir Temur, who ruled Samarkand in May 1409, [according to Sharafiddin Ali Yazdi]. "Said Baraka's dust was transferred from Andhud and buried in a sack of Sohibkiran.
Hazrat $^{1}$ (Amir Temur), according to his will, placed his (Said Baraka) legs on his legs. Amirzoda also surrendered Muhammad Sultan [body] to the gunbase and buried beside Amir Temur. " Subsequently, when the mausoleum was changed, the body of Muhammad Sultan was temporarily taken to another location [11]. About 15 years later, in 1425, Mirzo Ulugbek installed gravestones on graves and restored the eastern entrance to the complex. Rebuilding the front side of the inn is a squareshaped ensemble. In the West it builds two more towers similar to two towers on the opposite side of the yard.

At the end of the sixteenth century, Akbarshoh Baburi built a mosque, a terrace, a swimming pool and an old courtyard. It was during this period that the construction of a magnificent mausoleum (mausoleum) started by Amir Temur continued. According to Mutribi, after the death of Juhonmard Alikhon (16th century), the fundraising and restoration of the Guri Amir complex was suspended, and some of these works were carried out at the expense of the second time in India during his brother Abdulla Han. Frankly speaking, Amir Temur's majestic building could be constructed only in his time. Construction of the complex will not be completed. The southern and western structures of the old building will become ruins like the Muhammad Sultan madrasah and will remain under the houses built in the 19th and 20th centuries. The main parts of the remains of the foundations of these buildings are now discovered. This study will help to correct a number of shortcomings in the study of the history of the mausoleum of the Amir Temur Mausoleum.

\footnotetext{
${ }^{1}$ Hazrat means Sir
} 
In 1924, work was done to repair the sloping part of the dome of the mausoleum. During the temporary laying of the tombstones, four corners of the room were separated from each other, the sides were cut and the walls were covered with dense layers. These layers consist of several layers of plaster surface. The accurate location of the layers in the section suggests that architect Mauer, who carried out the research, could have formed only after the layers of the gypsum layers were formed after the building was constructed. Based on these opinions, the idea that the mesh in the mausoleum was initially smaller. Then it was expanded deeply by cutting the densely populated soil between the walls of the citadel and the mausoleum.

I.E. Pletnev and Y. Z.Shvab, who made excavations here, believed that the mausoleum was initially small. V.V.Bartold concludes on the basis of Zafarnoma data [12]. (See note).

During the study, it was discovered that not only the Muhammad Sultan ensemble, but also an architectural structure, which was also the largest, the largest ever known in Central Asia, was the mausoleum of Amir Temur. As a result of his vision of the new data-based monument, his step-by-step scientific and artistic reconstruction was accomplished.

\section{NOTE}

An extract from Mutrifiy al-Asamm's "Tarikhi Jahongiry" (History of Jahongir) (XVI-XVII centuries). A.Ahmedov. The mausoleum of Amir Temur // Zarafshon, September 23. 1995, Samarkand:

"The entrance to this mausoleum is on the north side and goes through a dome covered with dome. After that, you will enter the courtyard with fruit trees and shady trees. There is a swimming pool on the left side of the courtyard. Against the access road (at the end of the yard), there is another roof with a patterned tile. The mosque was built five times in front of that roof.

Nine hundred and eighty-two (1574) years, during the reign of Shayboniy, Muzaffar Akbarshoh sent it to the whole of the elephant (a fishing fleet) to restore Samarkand's mausoleum to Amir Temur because he (Akbarshoh) was the heir of Amir Temur.

One of the grandchildren of Khoja Akhror, Bakikhon Gani Tashkandiy, built a large aivan, large mosque on the western side of the mosque, where the Friday prayers were performed.

This is redirected through the roof and rectangular-shaped courtyard. Its surroundings are surrounded by a wall of about 40 gas $^{2}$. It has three towers in its three corners. Two of them have the second floor, called bouquet, with calligraphic patterns. There is access to the medrese on the left side of this yard. The medresseh is two stories and has about 60 rooms built by Mirzo Ulugbek Kuragon $^{3}(. .$.$) ... its two sides are covered with$ two high dome under the burial of the princes of Chigatay ...

There is also a roof overlooking the mausoleum on the right side of this courtyard ... There are several cabins and a huge boiler.

At the end of the yard, there is a large roofcovered roof, where visitors can pray. The

\footnotetext{
${ }^{2}$ Gas -is a unit of measurement

${ }^{3}$ Observatory
} 
entrance to the gallery, which leads to the mausoleum, is ...

In the mausoleum there are gravestones surrounded by white marbles. Frame shelves are located on all sides of the grille. Under the highest of them, on the front of the tabernacle is the Holy Koran of the great Emperor Ottoman ...

In the face of Mir Said Baraka's grave, there were four chests, which were handwritten by Muhammad Sulton's handwritten letters, which were deposited in this mausoleum.

Under the dome part of the tomb is decorated with gemstone, airy paint, bronze. The walls are made of colored glass candles.

Muzaffar shakh Juvonmard Alikhan spent gold (sent by Akbarshakh) for the repair of the madrasah, courtyard, tower and pool.

... This place was considered sacred during the reign of Sultan Abd al-Islam during the reign of Sultan Ibodullakh. But after his death, these places were again neglected ...

Said Sahih Mir Baraka Bukhari, one of the heirs of Amir Said Kulol (1620), has recently returned from India and brought many gold from there. The cost of expenditures, Tojiddin Hasan Khoja and Sirojiddin Abdurahim, made serious efforts to restore some of these sacred puddles ... but some areas have still been devastated."

\section{CONCLUSION}

Based on the above-mentioned historical and archaeological data, Amir Temur's Saga has reached a great extent in connection with the construction of five great men such as Sohibkiron Amir Temur and his beloved grandson Muhammad Sulton, his son Shohruh Mirzo, grandchildren Halil Sultan and Ulugbek Mirzo.

Today, this complex has become a unique architectural monument of the Uzbek people.

\section{REFERENCES}

1. I.E. Pletnev, Yu.Z. Shvab. On the question of burials in the crypt under the Gur - Emir mausoleum / Central Asia and its neighbors // antiquities and the Middle Ages. M .: Science, 1981, with $64-67$. See: with. 64.

2. V. V. Barthold. On the burial of Timur / Coll. Soch., T.II, p. 2, M .: Science, 1964, p. 423 - 454. See: p. 438.

3. A text from the text of the "Zafarnoma" manuscript by Sharafiddin Ali Yazdi, Tashkent: Fan, 1972, 457 - 934 b.

4. Pletnov I.E. Problems of research and experience in the restoration of the architectural complex "Gur - Emir" // Abstract of Cand. diss. - L .: 1969, p. 15 -17

5. Bartold V.V. About the burial of Timur. Notes of the eastern branch of the Russian Archaeological Society. t.23. SPb. M .: 1915 .

6. Bartold V.V. About the burial of Timur. Notes of the eastern branch of the Russian Archaeological Society. t.23. SPb. M .: 1915 .

7. Pletnev I.E., Shvab Yu.Z. Formation of complex architectural complexes near the mausoleums of Kusam-Ibn-Abbas and Gur-Emir / Materials and studies on the history and restoration of architectural monuments of Uzbekistan. Publishing Fiction them. Ghafura Ghulam. // T .: 1967.

8. Mankovskaya L.Y. "To study the techniques of Central Asian architecture ending in the XIV century. (Mausoleum of 
The American Journal of Engineering And Technology (ISSN - 2689-0984)

Published: September 10, 2020 | Pages: 1-12

Doi: https://doi.org/10.37547/tajet/Volume02Issue09-01

Khoja Ahmed Yasevi). Art of Architects of

Uzbekistan, ed. AN.USSSR, Tashkent, 1962

9. Omonullo Buriev "The Historical Geography of Central Asia in Written Sources of Timurid Period". "Monograph" Tashkent: 2017.

10. Vambery Armini. Travel in Central Asia. M .: Science, GRVL, 1873
11. Omonullo Buriev "Historical Geography of Central Asia in Written Sources of Timurid Period". "Monograph" Tashkent: 2017.

12. Bartold V.V. About the burial of Timur. Notes of the eastern branch of the Russian Archaeological Society. t.23. SPb. M .: 1915 .

\section{General view of the mausoleum of Amir Temur}

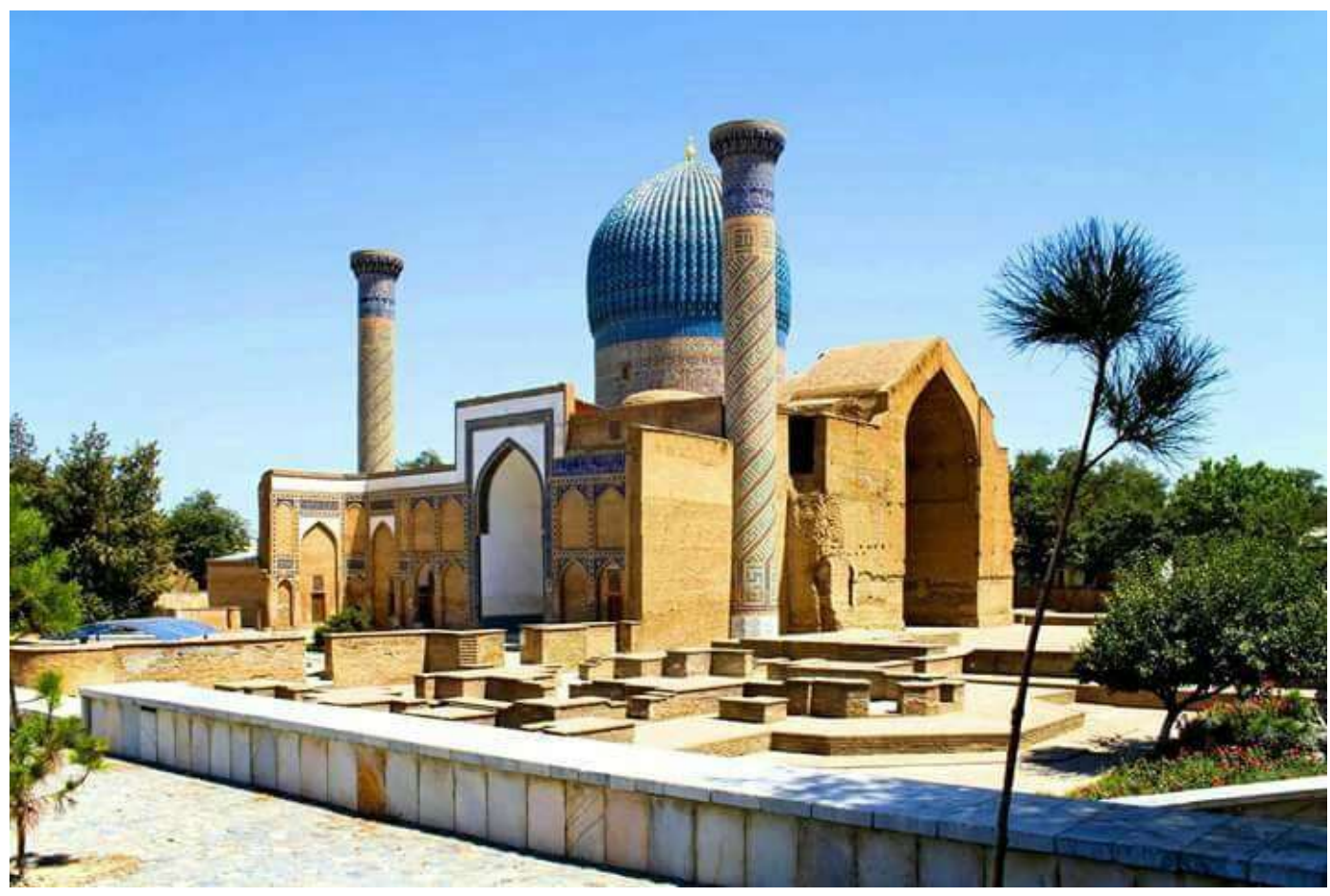




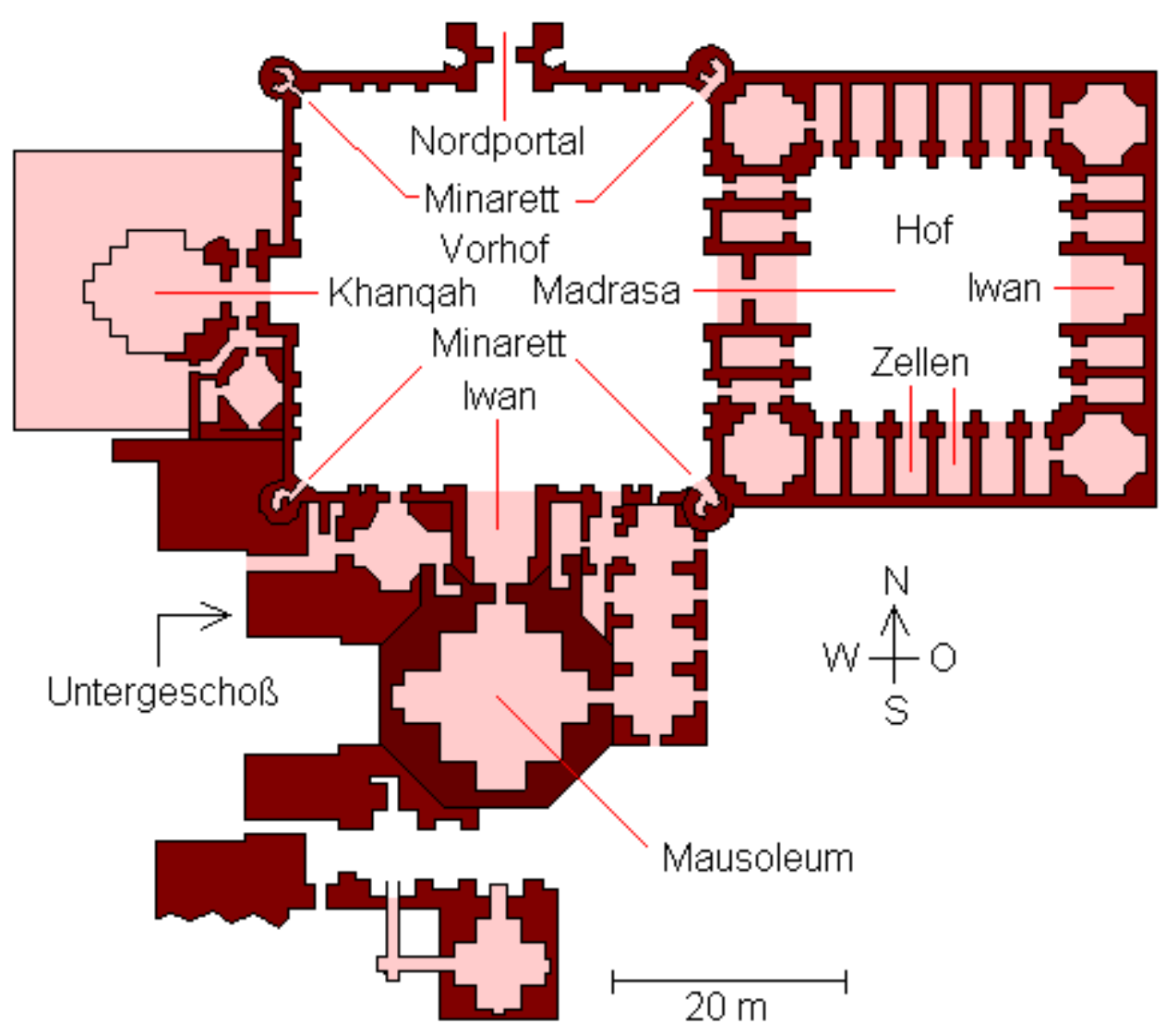

Amir Temur's mausoleum development (from the author)

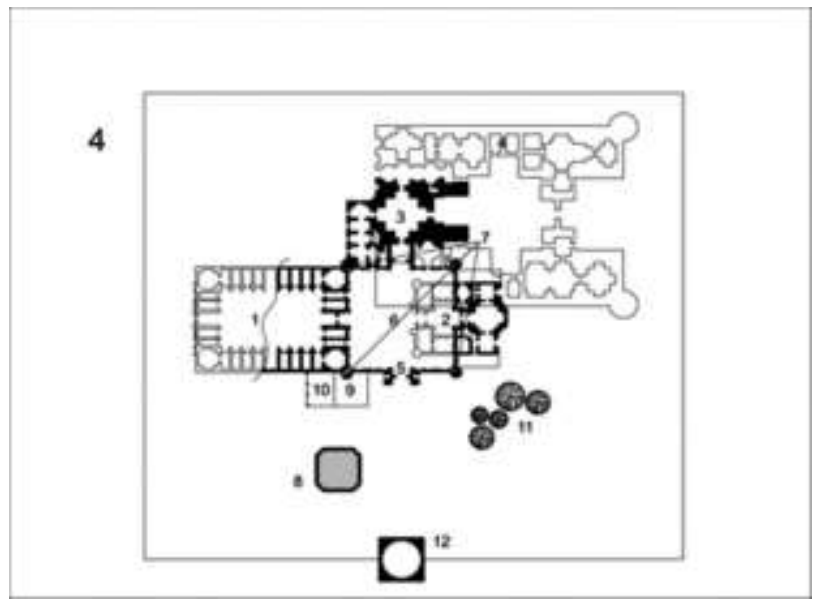

XVII century

1. Muhammad Sultan madrasah

2. Muslim Sultan's room

3. Amir Temur Mausoleum

4. A mausoleum that began to build Amir Temur

5. Peshtak, XV century

6. Garden built by Ulugbek

7. The towers of the XVII century

8. Pool, XVI-XVII centuries

9. Mosque, XVI-XVII centuries

10. Aivan

11. Bagh, XVI-XVII centuries

12. Chartak, XVII century 


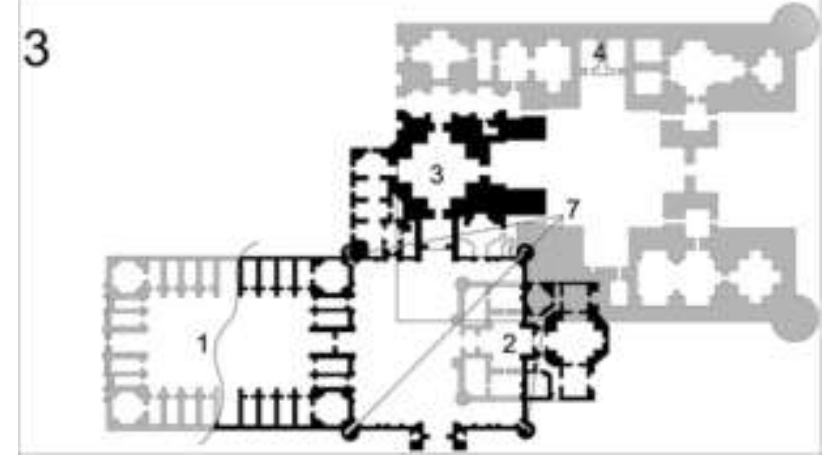

The state of the complex in the second quarter of the XVth century

1. Madrasa

2. Khonaqoh

3. Amir Temur Mausoleum

4. Muhammad Sultan foundation of the tomb

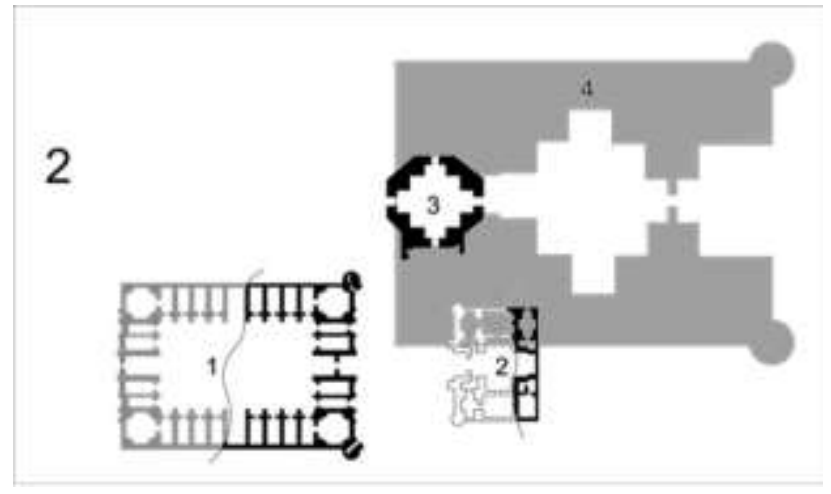

1404's complex status

1. Muhammad Sultan madrasah

2. Muslim Sultan's tomb

3. Amir Temur Mausoleum

4. A contour of Muhammad Sultan mausoleum which was began to be built by Amir Timur

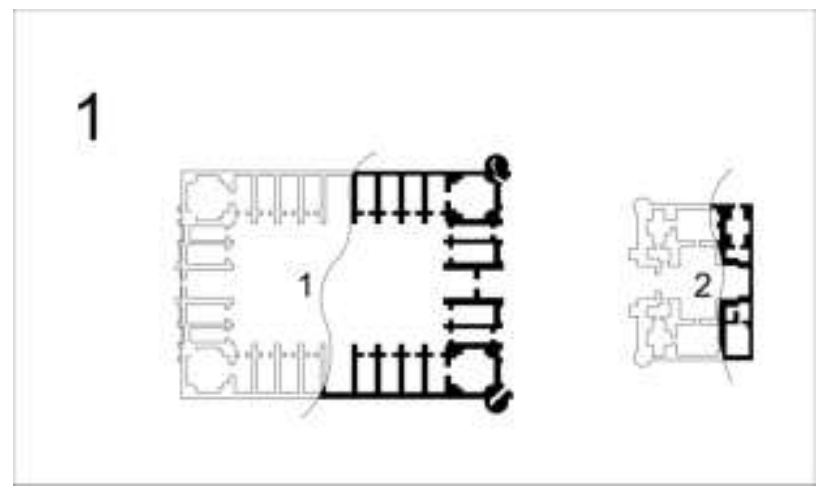

XV century Muhammad Sultan madrasah and Khonaqoh (tomb) 


\section{Madrasah}

2. Khonaqoh (tomb)

\section{Amir Temur Mausoleum Reconstruction (from author)}
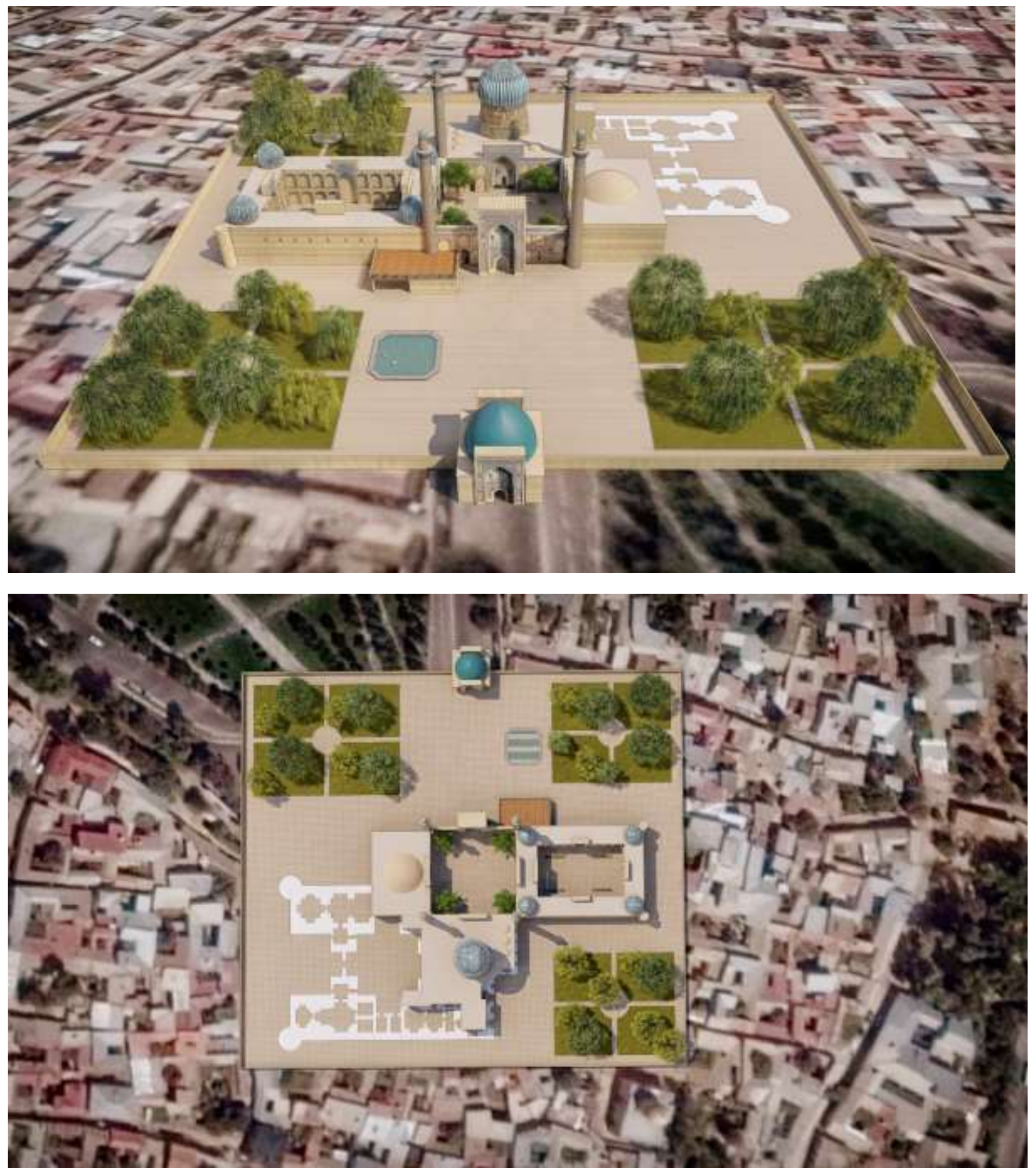